\title{
Suburbanization, land use of TOD and lifestyle mobility in the suburbs: An examination of passengers' choice to live, shop and entertain in the metro station areas of Beijing
}

\author{
Zhao Pengjun (Corresponding author) \\ Peking University \\ pengjun.zhao@pku.edu.cn
}

\author{
Li Shengxiao \\ Peking University \\ lishengxiao@pku.edu.cn
}

\begin{abstract}
In the process of suburbanization of large growing cities, transit passengers have an undeniable role to play in terms of local traffic, car use, and petrol consumption. It is widely believed that transitoriented development (metro station) could encourage people to live and consume near transit station areas through walking and cycling rather than travelling by car. However, opinions on this are still mixed. In addition, the existing literature is dominated by analyses of residents, while analyses of passengers remain scarce. This paper fills this gap by looking at metro station areas in Beijing. Using survey data, the study found mixed land use attracts passengers to shop more within metro station areas than in other places. More non-residential land developments attract more patrons to dine and access entertainment within metro station areas. Surprisingly, land use in the metro station areas was unrelated to passengers' choice to live within metro station areas, while housing prices and income had significant effects. Personal preferences for travel mode have an effect, and those who dislike travel tend to shop and seek entertainment locally. This study suggests that land-use planning in metro station areas could be helpful in shaping more sustainable mobility in the process of suburbanization of China's growing cities.
\end{abstract}

Keywords: suburbanization, transit-oriented development, land use, passengers, shopping trips, residential location

\section{Article history:}

Received: November 8, 2016

Received in revised form:

May 5, 2017

Accepted: November 5, 2017

Available online: February 12, 2018

\section{Introduction}

Suburbanization has been occurring in developed countries since the 1950s, with the population in the suburbs growing faster than in the urban areas (United Nations, 2001). This is due either to a rapid increase in the number of suburban residents coming from elsewhere or to the movement of people out of the city itself to the surrounding suburban areas. In North America and other developed countries, suburbanization is dominated by urban sprawl, which is defined in terms of "undesirable" land use patterns — whether scattered development, leapfrog development, strip or ribbon development, or

Copyright 2018 Zhao Pengjun \& Li Shengxiao

http://dx.doi.org/10.5198/jtlu.2018.1099

ISSN: 1938-7849 | Licensed under the Creative Commons Attribution - Noncommercial License 4.0

The Journal of Transport and Land Use is the official journal of the World Society for Transport and Land Use (WSTLUR) and is published and sponsored by the University of Minnesota Center for Transportation Studies. This paper is also published with additional sponsorship from WSTLUR. 
continuous low-density development (Ewing, 2008). There are many reasons for suburbanization, for example, lower land rates in the suburbs, the decline of living quality in urban areas due to pollution, crime, unemployment and traffic congestion, or the appearance of new business parks or shopping centers on the edge of cities (Glenn, 1973; Jordan, Ross, \& Usowski, 1998). Changes in lifestyle, for example, a rise in the standard of living and consumer preferences for larger homes and more private external space, also affect suburbanization (Mieszkowski \& Mills, 1993).

Since the 1980s, suburbanization has also appeared in some developing countries, for example, in China (Zhao, 2011; Zhao, 2013a), Africa (Buire, 2014; Kahimbaara, 1986), India and Mexico (Audirac, 2003). In China, suburbanization is happening in several ways. Firstly, as a result of the emerging real estate market in China, there is the emergence of suburban "gated communities," consisting of large spacious housing. Most of these communities are serviced by good motorways and main roads but have poor access to public facilities (e.g., schools, hospitals, public transport and jobs) (Wang \& Murie, 2000; Ping Wang \& Murie, 1996). Secondly, Chinese central government and local governments constructed many suburban industrial parks and launched many policies as facility and economic incentives to attract foreign companies, thus absorb foreign direct investment (FDI) and advanced technology (Walcott, 2002; Wei, Lu, \& Chen, 2009). Thirdly, there is urban sprawl in rural areas, characterized by illegal land use, poor housing conditions and the lack of basic urban facilities and infrastructure (Zhao, 2011).

In parallel with suburbanization, people's mobility has changed accordingly. One of the new changes is that people make more frequent use of their car and travel longer in the process of suburbanization (Gordon, Kumar, \& Richardson, 1989). A high dependence on the car and long travelling distances has become typical features of suburbanization in China, especially the metropolitans (Wang \& Zhou, in press). In particular, people tend to drive to shop, dine out or for entertainment. An auto-dependent suburban lifestyle has important effects on local transport and the environment. The prevalence of automobiles in China has brought many problems, such as air pollution, traffic congestion and higher risk of injuries (Wu et al., 2016; Huang, Yin, Schwebel, Li, \& Hu, 2016a). To promote sustainable mobility in suburbs has become a key issue in relation to sustainable suburbanization in China.

Transit-Oriented Development (TOD) is believed to have advantages in promoting sustainable mobility in the process of suburbanization. TOD is a form of development that anchors around a transit station, for example, a train station, metro station, tram stop, or bus stop. It has a center at the transit station or stop, surrounded by relatively high-density and mixed land development. TOD could promote sustainable mobility in the suburbs in many ways. For example, a high integration between transit and land use could reduce passengers' travel distance between home and the transit station and thus, possibly reduce car use (Cervero \& Murakami, 2009). A high design development in a metro station area is related to a higher level of transit ridership, which is vital for the daily maintenance of transit services (Cervero, 2004). Mixed land use in metro station areas, which is characterized by a distribution of a variety of public and commercial services nearby the transit station, might increase the number of trips made for local shopping and entertainment trips, and reduce the need for long-distance travel to the other places (Ratner \& Goetz, 2013). However, our existing knowledge about the effects of metro station on people's travel behavior has been dominated by cases from developed countries, such as cities from North America, Europe and Australia. China's cities have some unique features which make them different from the developed countries (Zhao, 2010; Zhao, 2011; Zhao, 2013b). Thus, conclusions based on cases from developed countries may not be applicable to Chinese cities (Pucher et al., 2007).

Since the 1990s, many large cities have invested in building and extending metro systems to cope with increasing urban populations and travel demand (Cervero \& Day, 2008; Huang, Cao, \& Cao, 2016c; Huang, Cao, Yin, \& Cao, in press; Zhang, Zheng, Sun, \& Wang, 2016). The total length of metropolitan metro lines in cities amounted to $2816 \mathrm{~km}$ by the end of 2014 (Zhongshang Industrial 
Research, 2016). Such rapid urban development and metro construction provide a great opportunity to implement metro station in China. In recent years, transit-oriented land development has been encouraged by central and local governments (Mu \& Jong, 2012; Doulet, Delpirou, \& Delaunay, 2017). The central government requires metro station to be encouraged as an important way to integrate land use and transit development, and as a way to improve transit services (The State Council, 2012). These requirements were laid out in the government's recent document (National Development and Reform Commission, 2014), which is the major strategic document guiding China's urban development in the near future. Many scholars claim that TOD may be an effective way to shape sustainable mobility in the future of China (Zhang, 2007; Doulet et al., 2017; Zhao, 2010; Zhao, Bin, \& De Roo, 2010).

Recent studies in China has paid attention to the role of proximity to metro stations on car ownership and sustainable mobility. Many studies found that proximity to metro station is negatively related to car ownership and car travel (Wang \& Wang, 2014; Huang, Cao, \& Cao, 2016b; Huang et al., in press). However, some studies found that the metro proximity does not significantly reduce car ownership and car travel (Shen, Chen, \& Pan, 2016). However, several gaps exist and make it hard to derive policies of transit-oriented development in Chinese cities. Firstly, the role of built environment in metro station areas on active travel is rarely considered, thus it is vague to derive the land use policies encouraging walking and cycling. Secondly, these studies mainly examine the impact of metro proximity on commuting travel and car ownership, while little is known about the impact of built environment in station areas on non-work destination choice and residential location choice. Therefore, the existing studies could provide limited evidence on business planning in metro station area from an individual consumer's perspective. Thirdly, suburban areas have significant potentials for transit-oriented development. This is because transit stations in suburbs mainly play the role of transport. Opening new metro station in suburban areas is mainly based on potential passengers nearby, while the land use development near the stations is often neglected (Doulet et al., 2017), and studies exploring the built environment in suburban metro stations on travel behaviors remain rare.

This paper examines the impacts of land use on transit users' decisions to live and consume in suburban transit station areas, using Beijing as an example. In addition to land use, we also investigate other variables which might affect individual users' decisions to live and consume in metro station areas, such as available transport services and individual preferences.

The article will be organized as follows: Section 2 elaborates on previous studies; Section 3 describes the survey, data and research methods; Section 4 presents the results of the data analysis and Section 5 discusses them; and lastly, Section 6 presents the conclusions and discusses the study's limitations and policy implications.

\section{Literature review: Land use of transit station area and travel behavior}

Many studies have examined the impacts of land use on people's residential location choice and nonwork travel behavior in transit (e.g., bus, metro, light rail, heavy rail, etc.) station areas. Land use in transit station areas is characterized by a wide variety of aspects, including area, type, density, urban design, presence of public facilities, etc. These aspects have been classified into the five "Ds": density, diversity, design, destination accessibility and distance to transit (Cervero, Sarmiento, Jacoby, Gomez, \& Neimam, 2009).

Residential and employment density are believed to be two of the most important factors influencing people's choices to reside and consume in transit station areas. Arrington and Cervero (2008) found that the higher the density, the higher the probability that people choose to live in transit station areas. However, employment density in transit station areas was found to be the most important influence on individual decisions of employment or residential location. In Australia, low density employment op- 
portunities around a station area are seen as a vital factor in the failure of TOD policies (Curtis, 2008). For non-work trips, Chatman (2013) found that a higher job density in rail station areas reduces car trips and increases shopping trips within them, even when demographic and lifestyle preference variables are controlled for.

Mixed land use is another important factor influencing people's choices of residential location and non-work travel in transit station areas. A transit station area with a variety of land use types can increase rates of non-work travel by non-motorized modes of transport (Frank \& Pivo, 1994). One of the reasons for this is that mixed land use creates a greater amount of space for shopping and entertainment, and a higher density of shops and grocery stores than in less mixed areas. This provides more destinations for people to choose from. It has been found that a high density of shops and grocers around transit station areas reduces automobile use and encourages people to do their shopping near the station (Handy, 1993; Handy, Cao, \& Mokhtarian, 2005; Loutzenheiser, 1997). This might be partly explained by the fact that passengers can buy goods when returning home from work (Cervero, 1996). When it comes to residential location choice, mixed land use metro station areas that have public facilities such as schools, libraries and sport centers are attractive to potential residents (Lund, 2006; Chatman, 2013).

Pedestrian-friendly urban design around transit station areas benefits the utility of nearby facilities and services. New urban designs, characterized by high numbers of street connections, can encourage local shopping trips in transit station areas (Handy, 1996). In relation to catering facilities around transit station stations, Cervero (2006) reported that pedestrian facilities are important for encouraging commuters to eat out at lunchtime, because most trips made at that time are by foot.

Access to transit stations, which is measured by the distance between transit stations and homes, is another important factor influencing passengers' choice of living and shopping in transit station areas. With shorter distances, there are greater possibilities for local shopping (Lund, Cervero, \& Wilson, 2004). Some researchers argue that the role of access to transit stations may affect passengers' travel choices more than all other variables. For example, some researchers found that when access is within 0.25 miles, other variables, such as variety of land use and pedestrian design, seem to matter little in determining their travel behavior in the station areas (Arrington \& Cervero, 2008). Other researchers doubt that proximity to transit stations is important in people's decisions about where to shop and dine out (Chatman, 2013).

Transport service availability in transit station areas is an important factor influencing people's decisions of housing location and non-work travel near metro stations. One is the metro system itself. Many researchers believe that reliable and convenient metro services encourage people to live and consume in transit station areas (Arrington \& Cervero, 2008). In turn, unpredictable transit delays may discourage people from using such services (Pratt, 2013). The other is bus services around transit stations. A high level of bus services linking transit stations encourages people to take a bus between home and the metro station, rather than driving (Chatman, 2013). Good bus connectivity between the workplace and daily activity locations might encourage people to consume around transit station areas (Thompson \& Matoff, 2000). Good accessibility of catering venues in transit station areas is important if residents are to patronize them (Cervero, 2006). However, some researchers argue that a high level of bus services may also encourage people to travel further and, thus, decrease the probability of them consuming in the vicinity of train stations (Edwards \& Mackett, 1996; Cervero, 2006).

There are spatial variations in the effects of land use on people's choice of residential location and non-work trips in transit station areas. Dittmar and Ohland (2012) compared travel behavior across different transit station areas and found that residents living in urban downtown transit station areas made more trips by public transport, walking and cycling than residents in suburban transit station areas, while the latter generated more driving trips. One of the reasons for this is that transit station in 
downtown areas is characterized by higher regional accessibility to the CBD. However, another reason is that many residents living close to urban downtown transit station areas are low-income earners who rely on transit services.

Apart from land use, there are other factors that influence passengers' choice of living and shopping in transit station areas. Firstly, individual personal preferences for housing and travel mode are important. Some previous studies argued that people tend to choose a residential location consistent with their travel preferences (Handy et al., 2006; Handy, Cao, \& Mokhtarian, 2005). This is called the selfselection mechanism. Many researchers have provided empirical evidence for the effects of self-selection on residential location decisions and travel behavior (Prashker, Shiftan, \& Hershkovitch-Sarusi, 2008; Bhat \& Guo, 2007). For example, there is a lifestyle preference for transit or non-motorized travel that leads people to reside near transit stations (Cervero \& Duncan, 2002; Switzer, 2002). Chatman (2013) reported that grocery trips made by residents living near transit stations were significantly related to personal residential preferences. Individual preferences for commodities are also important in determining non-work travel in transit station areas. For shopping, catering and entertainment, being able to choose from various options (e.g., from high quality to low price), and various kinds of products, is attractive to consumers in transit station areas (Niles \& Nelson, 1999).

Secondly, housing prices are also an important determinant of people's residential location choices in transit station areas. Generally, property and housing prices around transit station stations are higher the closer they are to the station (Bartholomew \& Ewing, 2011). A high housing price tends to force low-income earners to reside further away. This could increase their probability of using a motorized travel mode such as a car or bus between the station and their home, particularly in suburban areas (Cervero \& Duncan, 2002) and in Beijing (Gu \& Zheng, 2010). However, some researchers have also reported that transit proximity may cause declines in housing prices (Hess \& Almeida, 2007). This is partly explained by higher noise levels and potential crime hotspots near the transit stations studied (Bowes \& Ihlanfeldt, 2001). Thirdly, individual and family socioeconomic characteristics have effects on housing location and non-work travel behavior. Low-income earners without cars are more likely to reside around transit station stations (Olaru, Smith, \& Taplin, 2011; Lund et al., 2004). For non-work trips in transit station areas, some studies suggest that low-income households might be more likely to use amenities that are within walking distance because they lack access to other forms of transport (Lund, 2006). Residents who are renting may be more likely to shop and use catering facilities around station areas because of their low level of mobility (Chatman, 2013).

In summary, understanding the effects of land use on passengers' choice to reside and consume is crucial to implementing TOD policy to shape a more sustainable mobility in suburb. Many empirical studies have shown the links between land use and people's travel behavior and their choice to reside in a transit station area. However, the conclusions are clearly still mixed. In addition, the existing empirical studies are dominated by explorations of effects on residents, while studies on the effects on passengers remain scarce. Moreover, people's choices of living and consuming in metro station areas could also be affected by their preferences for travel and residential location. This is usually neglected in the existing literature. This study aims to fill these research gaps by looking at the case of Beijing.

\section{Case, data and methods}

\subsection{City context}

Beijing is chosen as the case in this study because it has the biggest and earliest metro system nationwide. Although the government has invested intensively on suburban metro system, the trend of motorization is still hard to deter. An important reason for this is that the land use development around the metro 
stations is far from meeting the daily non-work needs of the passengers. This paper aims to explore the determinants of passengers' consumption and residential decisions in metro station areas in Beijing, and derive planning implications to attract passengers to consume and live in metro station areas. This study would be expected to shed light on transit-oriented planning in high-density and transit-dependent metropolitans like Beijing worldwide.

Beijing is the capital of China, and had a population of 21.75 million and a land area of 16, 410 $\mathrm{km} 2$ in 2015 (BMBS, 2015). The city is divided into four areas: the core urban area, the main urban area, the inner-suburban area, and the ecological conservation area (Figure 1). The overall size of the population in Beijing has been rapidly increasing since the 1980s. There were 10 million people added to the population in during the period 1990-2015. Since the 1990s, a trend of suburbanization has appeared in Beijing (Zhao, 2013a; Zhao, 2013b). As shown in Figure 2, the inner suburban area has had a continuous increase in population for all areas since 1995. In particular, the growth of the proportion of population in the inner suburban area increased rapidly after 2010 .

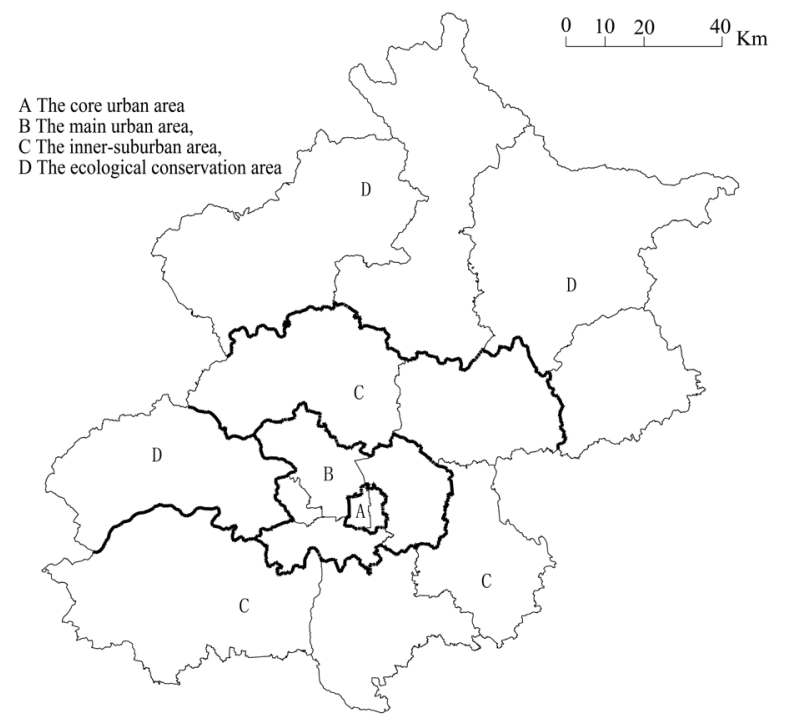

Figure 1: The administrative range of Beijing

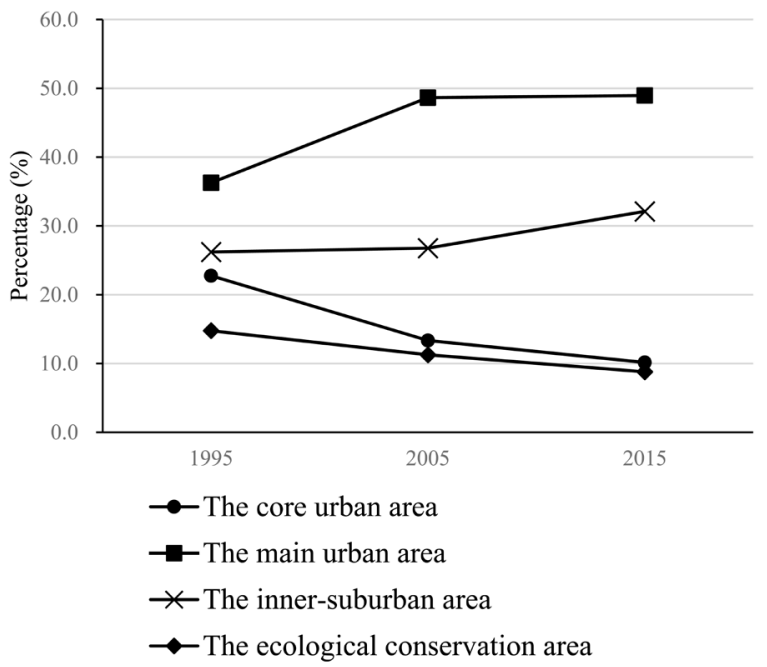

Figure 2: The changes in population growth in Beijing

Some new features of individual people's mobility have arisen in the process of suburbanization. 
Suburban people, including transit passengers, tend to travel more, travel longer and use their car more often than the residents in the urban area (Table 1). Table 1 shows that the suburban residents had more trips than the urban residents. Lifestyle related trips, for example, shopping, dining and entertainment trips, accounted for more than 30 percent of the total trips. Both the amount of car trips and trip distance by car are higher in the suburban areas than in the urban areas. Reducing the trips made by suburban people are vital to the reduction of car use and oil consumption in Beijing.

Table 1: Individual people's mobility features in Beijing in 2010

\begin{tabular}{|l|l|c|c|}
\hline Personal mobility & Measurement & The suburban areas & The urban areas \\
\hline Trips & The number of trips per day per capita & 2.98 & 2.64 \\
\hline Car ownership & Cars per 1000 people & 110 & 121 \\
\hline Trips by car & Percentage of car trips of total trips made (\%) & 11.84 & 11.46 \\
\hline Trips by metro & Percentage of metro trips of total trips made (\%) & 17.96 & 12.81 \\
\hline Trip distance & Distance per trip $(\mathrm{km})$ & 9.1 & 8.8 \\
\hline Car trip distance & Distance per trip by car $(\mathrm{km})$ & 11.7 & 10.5 \\
\hline Percentage of non-work trips & $\begin{array}{l}\text { Percentage of non-work trips of total trips made } \\
\text { (\%) (inc. shopping, dining, entertainment, etc.) }\end{array}$ & 31.5 & 32.2 \\
\hline
\end{tabular}

Note: 1) Data source: the author, edited from Beijing Transportation Research Center (2013); 2) The suburban areas include the inner suburban area and the ecological conservation area, and the urban areas include the core urban area and the main urban area.

A large number of metro lines was developed in order to meet travel demand and reduce car use in the suburb. Eighteen metro lines with a total length of $530 \mathrm{~km}$ had been built by 2014 (Figure 3). Several more metro lines are currently under construction, with the total length of the metro to reach 660 $\mathrm{km}$ in 2016. In the meantime, metro station has been encouraged by the government. The Beijing City Master Plan 2004-2020 (Beijing Municipal Commission of Urban Planning, 2005) requires that metro lines and stations should be treated as a primary force to reshape urban structures and land use towards a more sustainable urban form. TOD should be encouraged across the entire city and along all lines to achieve a high integration between metro development and land development. The Beijing Metro Construction Plan (2007-2015) states that TOD should be a good way of reducing long-distance travel and car dependence in the suburb. In practice, TOD in Beijing is implemented by the government transport department, the planning department and private land developers. Several government-led TOD pilot projects have also been implemented. For example, Changyang was the first station to be planned and developed as a TOD area, with the land development and metro line construction being undertaken together. Land development in this metro station area was led by the state-owned Beijing Metro Operation Company. There are now other government-led TOD areas, such as Liuliqiao, Yongfengnan and Nanguan. 


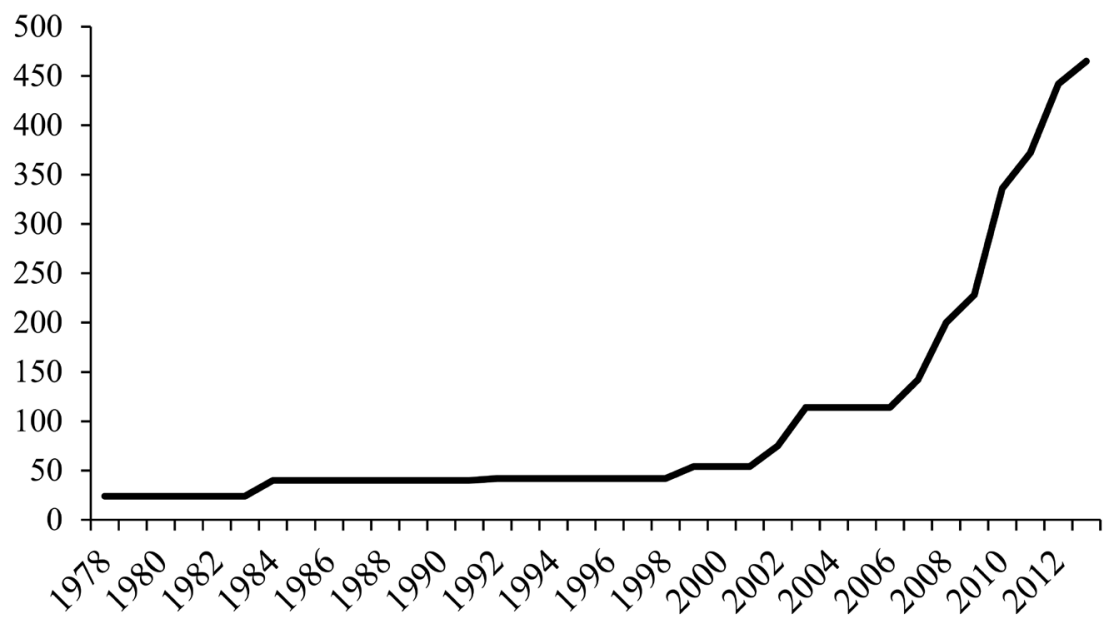

Figure 3: The total length of metro lines in Beijing $(\mathrm{km})$

\subsection{Survey and data}

The data used in the study comes from a survey conducted by the Center for Urban and Transport Planning Research, Peking University, Beijing, from March to May 2015. Seven suburban metro stations were chosen for examination: Pingxifu, Changyang, Yihezhuang, Guozhan, Liyuan, Cuigezhaung and Tongzhoubeiguan (shown in Figure 4). These stations are chosen in terms of their location according to the city center of Beijing. They are representative of the suburban metro areas in Beijing in terms of the built environment of precincts. A site survey was conducted at each station. The investigators randomly choose metro passengers boarded or embarked at the above target stations between 5 and 7 PM. They conduct face-to-face interviews with the target respondents and may travel with the passengers for several stops to finish the survey. The target questionnaires for every station is fifty. The passengers were asked to report their travel behaviors, employment, housing situation, personal attributes and socioeconomic status. A total of 306 questionnaires were collected, but after omitting questionnaires with missing data, a sample of 284 remained for analysis. It is acknowledged that the samples size is small. However, it could be representative since all respondents were chosen randomly. Among all the samples, 44 of them are employees rather than residents in seven metro precincts, and 10 of them are devoid of residential location information. Thus, in the descriptive statistics and the model for residents, only 230 samples are remained for analysis. Table 2 demonstrates the descriptive statistics of key variables in the survey. 


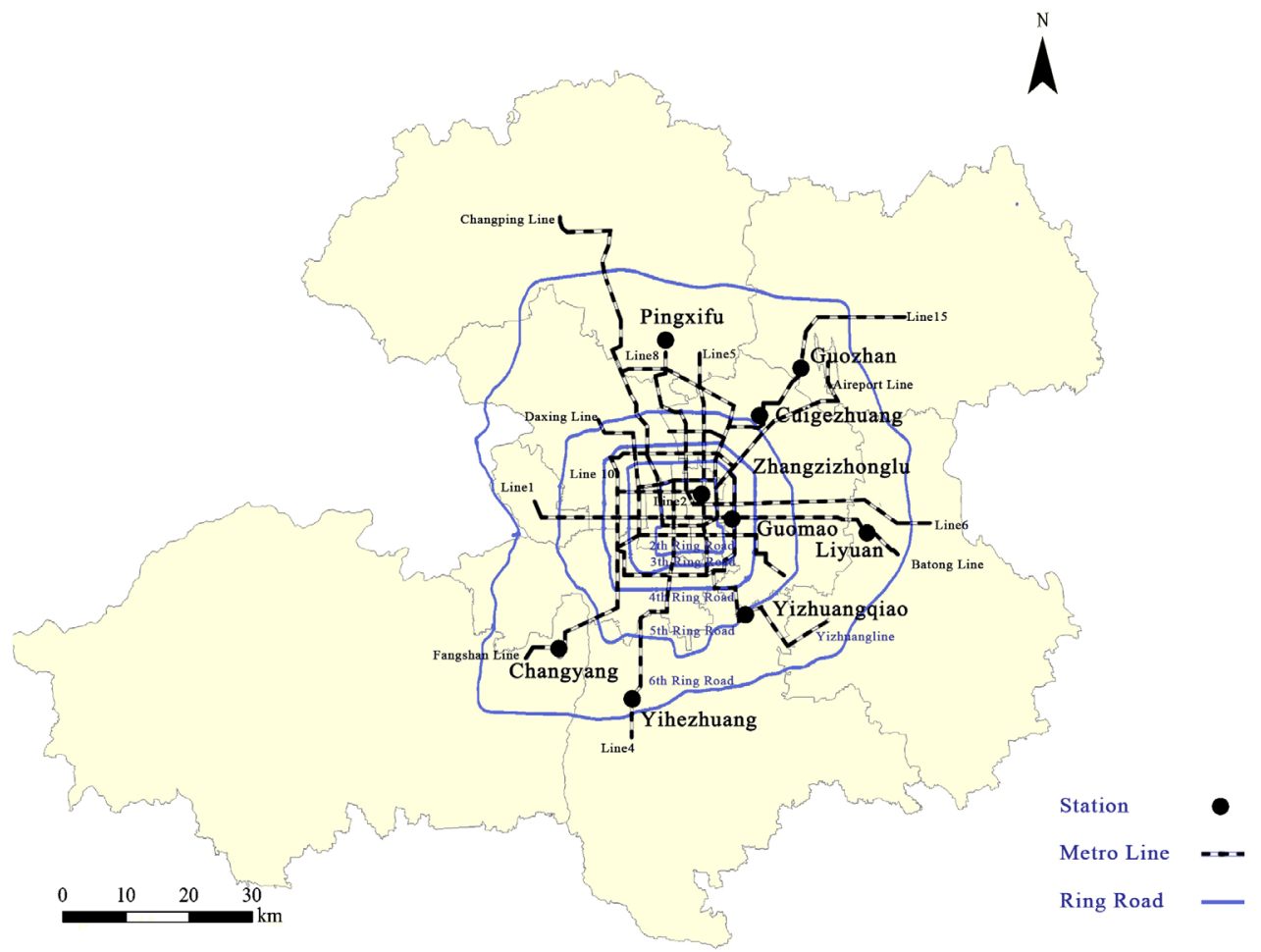

Figure 4: Metro station areas examined in the research 
Table 2: Description of the key variables in the survey

\begin{tabular}{|c|c|c|c|c|}
\hline Variables & Category/Unit & $\begin{array}{c}\text { Number of } \\
\text { samples }\end{array}$ & $\begin{array}{c}\text { Amount of } \\
\text { cases or mean }\end{array}$ & $\begin{array}{l}\text { Percentage/ } \\
\text { Standard Error }\end{array}$ \\
\hline \multirow{2}{*}{ Residing in TOD area } & Residing in TOD area $(=1)$ & \multirow{2}{*}{230} & 147 & 53.65 \\
\hline & Residing outside TOD area $(=0)$ & & 83 & 30.29 \\
\hline Shopping in TOD area & $\begin{array}{l}\text { The number of trips during one week } \\
\text { period in TOD area }\end{array}$ & 283 & 2.13 & 0.16 \\
\hline $\begin{array}{l}\text { Catering and entertainment } \\
\text { in TOD area }\end{array}$ & $\begin{array}{l}\text { The number of trips during one week } \\
\text { period in TOD area }\end{array}$ & 283 & 0.96 & 0.91 \\
\hline Access to metro station & $\begin{array}{l}\text { Distance from home to metro station } \\
\text { (Kilometres) }\end{array}$ & 274 & 1.52 & 0.12 \\
\hline \multirow{2}{*}{ Gender } & Female & \multirow{2}{*}{284} & 123 & 43.31 \\
\hline & Male & & 161 & 56.69 \\
\hline \multirow{2}{*}{ Age } & Below 30 & \multirow{2}{*}{284} & 202 & 71.13 \\
\hline & Above 30 & & 82 & 28.87 \\
\hline \multirow{2}{*}{ Monthly income } & $<5000$ (Chinese Yuan) (Low income) & \multirow{2}{*}{284} & 105 & 36.97 \\
\hline & $>5000$ (Chinese Yuan) (High income) & & 179 & 63.03 \\
\hline \multirow{2}{*}{ Car ownership } & Yes $(=1)$ & \multirow{2}{*}{284} & 98 & 34.51 \\
\hline & No $(=0)$ & & 186 & 65.49 \\
\hline \multirow{2}{*}{ Housing ownership } & Renting house $(=0)$ & \multirow{2}{*}{284} & 200 & 70.42 \\
\hline & Own house $(=1)$ & & 84 & 29.58 \\
\hline \multirow{2}{*}{$\begin{array}{l}\text { Preference for metro trans- } \\
\text { port }\end{array}$} & Yes $(=1)$ & \multirow{2}{*}{284} & 154 & 54.23 \\
\hline & No $(=0)$ & & 130 & 45.77 \\
\hline \multirow{2}{*}{ Preference for driving } & Yes $(=1)$ & \multirow{2}{*}{284} & 26 & 9.15 \\
\hline & No $(=0)$ & & 258 & 90.85 \\
\hline \multirow{2}{*}{ Dislike travel } & Yes $(=1)$ & \multirow{2}{*}{284} & 200 & 70.42 \\
\hline & No $(=0)$ & & 84 & 29.58 \\
\hline \multirow{2}{*}{$\begin{array}{l}\text { Preference for goods or } \\
\text { services diversity }\end{array}$} & Yes $(=1)$ & \multirow{2}{*}{284} & 24 & 8.45 \\
\hline & No $(=0)$ & & 260 & 91.55 \\
\hline \multirow{2}{*}{$\begin{array}{l}\text { Preference for cheap goods or } \\
\text { services }\end{array}$} & Yes $(=1)$ & \multirow{2}{*}{284} & 11 & 3.87 \\
\hline & No $(=0)$ & & 273 & 96.13 \\
\hline
\end{tabular}

The built environment variables of each station precincts are retrieved by ArcGIS using spatial data of Baidu Map. In this study, a metro station area is defined as a circle with a $1.5 \mathrm{~km}$ radius and a metro station at the center. It should be noted that in previous case studies in North American or Australian cities, a metro station area usually has a radius of 400 meters (or $1 / 4$ mile). The distance of $1.5 \mathrm{~km}$ used in this paper is larger than that of these previous studies and there are several reasons for this. According to a recent survey in China, $94.9 \%$ of walking trips made to metro station areas take less than 20 minutes, which is equivalent to approximately 1,500 meters (Du \& Jiang, 2005). Another study found that when the distance to a metro station is more than $1.5 \mathrm{~km}$, people are more prone to using motorized travel (Huang, Guan, \& Yan, 2009). In addition, according to the data used in the present study, the trips to and from the metro stations by walking were mostly (99.52\%) within 20 minutes (Table 3 ). Hence, a radius of $1.5 \mathrm{~km}$ is reasonable for a metro station area.

Table 3: Duration of walking trips between transit stations and origins/destinations

\begin{tabular}{|l|c|c|c|c|c|}
\hline Time (minutes) & $0-5$ & $6-10$ & $11-15$ & $16-20$ & $>20$ \\
\hline Cases & 53 & 116 & 32 & 7 & 1 \\
\hline Cumulative percentage (\%) & 25.36 & 80.86 & 96.17 & 99.52 & 100 \\
\hline
\end{tabular}


Table 4: Descriptive data of seven metro precincts

\begin{tabular}{|c|c|c|c|c|c|c|c|c|}
\hline & Pingxifu & Changyang & Yihezhuang & Guozhan & Liyuan & Cuigezhuang & Tongzhoubeiguan & Yizhuangqiao \\
\hline Number of samples & 50 & 51 & 43 & 23 & 25 & 22 & 50 & 20 \\
\hline $\begin{array}{l}\text { Distance to Tian'anmen } \\
\text { Square }(\mathrm{km})\end{array}$ & 21 & 22.5 & 22.8 & 22.2 & 23.2 & 15.2 & 22.6 & 13.8 \\
\hline residential households & 22336 & 22334 & 8751 & 6073 & 39589 & 3674 & 15016 & 16698 \\
\hline land use entropy & 0.24 & 0.4 & 0.57 & 0.62 & 0.48 & 0.6 & 0.48 & 0.57 \\
\hline $\begin{array}{l}\text { Area of non-residential land } \\
(10 \text { thousand } \mathrm{m} 2)\end{array}$ & 6.78 & 15.55 & 20.89 & 23.42 & 19.39 & 9.62 & 14.68 & 13.14 \\
\hline $\begin{array}{l}\text { Density of the branch ways } \\
(\mathrm{m} / \mathrm{km} 2)\end{array}$ & 2757 & 7959 & 1979 & 3202 & 2667 & 2436 & 4500 & 1979 \\
\hline $\begin{array}{l}\text { metro service } \\
\text { interval(seconds) }\end{array}$ & 240 & 420 & 112 & 300 & 300 & 300 & 210 & 360 \\
\hline Number of bus lines & 24 & 14 & 24 & 17 & 30 & 8 & 37 & 23 \\
\hline Housing price & 27639 & 21107 & 18854 & 23778 & 22644 & 44958 & 22968 & 27710 \\
\hline $\begin{array}{l}\text { Income }<5000 \mathrm{RMB} / \\
\text { month (\%) }\end{array}$ & 40.00 & 33.33 & 55.81 & 26.09 & 44.00 & 40.91 & 24.00 & 30.00 \\
\hline Car ownership (\%) & 12.00 & 35.29 & 41.86 & 39.13 & 12.00 & 27.27 & 62.00 & 35.00 \\
\hline Housing ownership (\%) & 16.00 & 49.02 & 25.58 & 21.74 & 20.00 & 22.73 & 36.00 & 35.00 \\
\hline $\begin{array}{l}\text { Average number of weekly } \\
\text { shopping trips }\end{array}$ & 0.48 & 1.02 & 0.84 & 0.78 & 1.92 & 1.50 & 0.90 & 0.90 \\
\hline $\begin{array}{l}\text { Average number of weekly } \\
\text { dining/recreation trips }\end{array}$ & 2.80 & 1.36 & 3.26 & 2.26 & 2.54 & 2.91 & 0.84 & 1.60 \\
\hline $\begin{array}{l}\text { Percentage of passengers liv- } \\
\text { ing in TOD precincts }(\%)\end{array}$ & 87.76 & 73.81 & 58.33 & 70.00 & 57.14 & 82.35 & 83.67 & 50.00 \\
\hline
\end{tabular}

\subsection{Methods}

The key research questions concern how land use affects passengers' choices to reside and/or consume in metro station areas. Three models were examined to answer this. The first and the second models investigated the determinants of passengers' choices of consumption in metro station areas. The dependent variables were the number of trips taken for the purposes of shopping, catering or entertainment. In these two models, the dependent variables are concrete non-negative integers. Count regression models (e.g., Poisson regression or negative binomial regression) are often used to measure trip counts (Handy et al., 2006). Negative binomial regression can be regarded as a specific version of Poisson regression (Hilbe, 2011). When the variance of the data is larger than the mean, negative binomial model rather than Poisson is used (Hilbe, 2011). This model is good at dealing with models whose dependent variables are over-dispersed count variables. Therefore, this study applied negative binomial regression to examine the second and third models. However, it should be noted that this model could underestimate the over-dispersed samples (David, 2010). The third model was a regression model to examine whether the residents choose to live near the metro station or not. A binomial logit model was used to examine whether a passenger chooses to reside in a metro station area or not, because the dependent variable is a dichotomous variable. 


\section{$4 \quad$ Analysis}

\subsection{Shopping in metro station areas}

Table 5 shows the results of the analysis of the determinants of a passenger's shopping trips in a metro station area. The number of trips was significantly related to land use. The higher the land use mix, the more shopping trips were made $(\operatorname{IRR}=1.067, \mathrm{p}<0.01)$. Mixed land use in a metro station area can encourage people to shop near the transit station. One major reason for this is that mixed land use, with commercial, retail and public facilities, provides a greater choice of goods and services (Lund, 2006; Chatman, 2013).

The results show that transport services have effects on passengers' shopping trips in metro station areas. The presence of bus services tends to encourage shopping trips (IRR $=1.435, \mathrm{p}<0.01)$. This means that better bus services in metro station areas encourage passengers to do their shopping there, which is consistent with previous studies (Cervero, 2006; Thompson \& Matoff, 2000). A larger metro headway could be related to more shopping trips near transit stations ( $I R R=1.056, p<0.05)$. One of the main reasons for this might be that lower service frequencies result in long waiting times. Passengers might use this time to do their shopping in the area.

It is worth noting that people who dislike travel are more likely to shop around the stations. The effect is statistically significant $(\mathrm{p}<0.01)$. The coefficient of 2.035 means that people who dislike travel have an incidence rate ratio 2.035 times higher than those who do. The results suggest that shopping trips made near the transit stations are partly due to people's dislike of long-distance or time-consuming travel.

Table 5: Regression results for passengers' weekly shopping trips in metro station areas

\begin{tabular}{|c|c|c|c|}
\hline & & Incident rate ratio (IRR) & Standard error \\
\hline \multicolumn{4}{|l|}{ Land use } \\
\hline \multicolumn{2}{|c|}{ Area of the existing non-residential land } & 0.948 & 0.035 \\
\hline \multicolumn{2}{|c|}{ Land use mix } & $1.067^{* * *}$ & 0.019 \\
\hline \multicolumn{2}{|c|}{ Density of the branch roads } & $0.869^{* *}$ & 0.051 \\
\hline \multicolumn{2}{|c|}{ Regional accessiblity } & 1.118 & 0.082 \\
\hline \multicolumn{2}{|c|}{ Access to metro station } & 0.986 & 0.516 \\
\hline \multicolumn{4}{|c|}{ Transport services } \\
\hline \multicolumn{2}{|c|}{ Metro service interval } & $1.435^{* * *}$ & 0.176 \\
\hline \multicolumn{2}{|c|}{ The number of bus service lines } & $1.056^{* *}$ & 0.025 \\
\hline \multicolumn{4}{|c|}{ Household socioeconomic features } \\
\hline \multicolumn{2}{|c|}{ Housing price } & 1.108 & 0.118 \\
\hline \multicolumn{2}{|c|}{ Monthly income: above RMB 5000} & 0.786 & 0.156 \\
\hline \multicolumn{2}{|l|}{ Car ownership } & 1.238 & 0.299 \\
\hline \multicolumn{2}{|c|}{ Housing ownership } & 0.99 & 0.247 \\
\hline \multicolumn{4}{|c|}{ Individual personal preferences } \\
\hline \multicolumn{2}{|c|}{ Preference for metro transport } & 0.885 & 0.173 \\
\hline \multicolumn{2}{|c|}{ Preference for driving } & 0.754 & 0.253 \\
\hline \multicolumn{2}{|l|}{ Dislike travel } & $2.035^{* * *}$ & 0.506 \\
\hline \multicolumn{2}{|c|}{ Preference for diversity of goods and services } & 0.661 & 0.307 \\
\hline \multicolumn{2}{|l|}{ Intercept } & $0.002^{*}$ & 0.007 \\
\hline Observations & 273 & $\mathrm{Chi}^{2}$ & 35.33 \\
\hline $\mathbf{L L}$ & -351.6 & sig & 0.0036 \\
\hline LR test value & 67.35 & AIC & 2.766 \\
\hline sig & 0 & BIC & -682.336 \\
\hline
\end{tabular}




\subsection{Dining and entertaining in the metro station areas}

Table 6 shows the results of the analysis of the determinants of passengers' trips for consuming food, drinks and entertainment in metro station areas. Land use plays an important role. The size of nonresidential land development in a metro station area is significantly related to the number of dining and entertainment trips. A greater size encourages a higher frequency of dining and entertainment trips near the transit station (IRR $=1.057, \mathrm{p}<0.1$ ). One of the major reasons for this is that large scale nonresidential land developments have a large number of non-residential facilities available in the metro station area, such as supermarkets, grocery stores, restaurants, etc. A high density of branch roads is negatively related to more dining and entertainment trips in metro station areas (IRR=0.849, $\mathrm{p}<0.01)$. This negative relationship could also be explained like that in the shopping model.

Table 6: Regression results for passengers' weekly dining and recreation trips in metro station areas

\begin{tabular}{|c|c|c|c|}
\hline & & Incident rate ratio (IRR) & Standard error \\
\hline \multicolumn{4}{|l|}{ Land use } \\
\hline \multicolumn{2}{|c|}{ Area of non-residential land } & $1.057^{*}$ & 0.337 \\
\hline \multicolumn{2}{|l|}{ Land use mix } & 1.013 & 0.155 \\
\hline \multicolumn{2}{|c|}{ Density of the branch roads } & $0.849^{* * *}$ & 0.449 \\
\hline \multicolumn{2}{|c|}{ Regional accessibility } & $1.116^{*}$ & 0.677 \\
\hline \multicolumn{2}{|c|}{ Access to metro station } & 0.927 & 0.041 \\
\hline \multicolumn{4}{|c|}{ Transport services } \\
\hline \multicolumn{2}{|c|}{ Metro service interval } & 1.089 & 0.119 \\
\hline \multicolumn{2}{|c|}{ The number of bus service lines } & 1.007 & 0.213 \\
\hline \multicolumn{4}{|c|}{ Household socioeconomic features } \\
\hline \multicolumn{2}{|l|}{ Housing price } & $1.376^{* * *}$ & 0.13 \\
\hline \multicolumn{2}{|c|}{ Monthly income: above RMB 5000} & 1.201 & 0.207 \\
\hline \multicolumn{2}{|l|}{ Car ownership } & $1.422^{*}$ & 0.3 \\
\hline \multicolumn{2}{|c|}{ Housing ownership } & 0.756 & 0.162 \\
\hline \multicolumn{4}{|c|}{ Individual personal preferences } \\
\hline \multicolumn{2}{|c|}{ Preference for metro transport } & 0.94 & 0.161 \\
\hline \multicolumn{2}{|c|}{ Preference for driving } & 0.836 & 0.25 \\
\hline \multicolumn{2}{|c|}{ Dislike travel } & $2.215^{* * *}$ & 0.472 \\
\hline \multicolumn{2}{|c|}{ Preference for diversity of goods and services } & 0.616 & 0.247 \\
\hline \multicolumn{2}{|l|}{ Intercept } & $0.006^{* *}$ & 0.002 \\
\hline Observations & 273 & Chi2 & 53.51 \\
\hline $\mathbf{L L}$ & -496.27 & sig & 0 \\
\hline LR test value & 181.09 & AIC & 3.826 \\
\hline sig & 0 & BIC & -393.003 \\
\hline
\end{tabular}

Note: ${ }^{* * *}$ indicates significant at $\mathrm{p}<0.01,{ }^{* *}$ indicates significant at $\mathrm{p}<0.05$, and ${ }^{*}$ indicates significant at $\mathrm{p}<0.1$

Regional accessibility, which is measured by the distance from a metro station to the $\mathrm{CBD}$, is significantly related to the number of dining and entertainment trips made in metro station areas. With every kilometer of distance from the $\mathrm{CBD}$, there is an $11.6 \%$ increase in dining and entertainment trips made near transit stations $(\mathrm{p}<0.1)$. This reveals spatial variations in the effects of land use on dining and entertainment trips in metro station areas. One important reason for this result is that residents living far 
from the city center should take more time and money to go to other activity destinations other than the station precincts. Another reason is that metro stations far from the city center (e.g., Changyang, Liyuan and Tongzhoubeiguan) are more developed in business than the stations nearer to the city center (e.g., Cuigezhuang and Yizhuangqiao) (Table 4).

Housing prices also affect dining and entertainment trips in metro station areas. Higher housing prices in the precincts are correlated with more dining and entertainment trips (IRR=1.376, $\mathrm{p}<0.01$ ). There could be many reasons for this. One of these is that goods and services in metro station areas usually cost more due to higher land and rent prices. While people who live in an expensive house in a metro station area might be able to afford local dining and entertainment services, low-income earners may have to go elsewhere.

Personal preferences for travel also affect dining and entertainment trips in metro station areas. Passengers who dislike travelling are much more likely to make these trips within the metro station areas $(\operatorname{IRR}=2.215, \mathrm{p}<0.01)$. This suggests that dining and entertainment facilities in metro station stations would be attractive to people who prefer short-distance travel.

\subsection{Residential location choice in the metro station areas}

Table 7 shows the regression results for the determinants of passengers' residential location choice in the metro station areas. It is interesting that most variables of land use have no significant effects on a passenger's residential location choice when housing price and income are taken into account. Regional accessibility (distance to the $\mathrm{CBD}$ ) is significantly related to a passenger's choice of residing in a metro station area $(\mathrm{p}<0.1)$. When a metro station is located further from the city center, a passenger has a higher probability of choosing to reside in it. One of reasons for this may be that metro station areas in the suburbs have a relatively higher level of concentration of retail and commercial services than other places in that suburb.

Housing price is one of the most important factors related to a passenger's choice to reside in a metro station area. Metro passengers from a community with a higher housing price are more likely to reside in a metro station area than those from communities with lower housing prices $(\mathrm{p}<0.01)$. One of the reasons for this is that on average, in the suburbs of Beijing, housing prices are higher in metro station areas than other areas. Many empirical studies in Beijing found the positive effect of metro proximity on housing property value (Zheng \& Kahn, 2013; Sun, Zheng, \& Wang, 2015), especially in suburban areas (Gu \& Zheng, 2010). Those who live in metro station areas are most likely to be middle- or high-income earners because they can afford housing close to station areas, while low-income earners may have to live further away. This is consistent with the results of the analysis of the relationship between income and the choice of residing in a metro station area. Table 5 shows that a passenger from a high-income household (monthly income above RMB 5000) is more likely to reside in a metro station area $(\exp (b)=1.568, \mathrm{p}<0.1)$ than a passenger from a low-income household. metro station

The results in Table 7 show that personal preferences for travel have no significant relationship with a traveler's choice to reside in a metro station area. Some believe that residential location choice is affected by preferences for a given travel mode. This is explained by the self-selection argument (Handy et al., 2005). However, the results above show that in metro station areas of Beijing, personal preferences for travel may not be an important factor in residential location choice when other factors are taken into account. 
Table 7: Regression results for traveler residential choice in metro station areas

\begin{tabular}{|c|c|c|c|}
\hline & B & Standard error & $\operatorname{Exp}(B)$ \\
\hline \multicolumn{4}{|l|}{ Land use } \\
\hline Land use mix & -0.07 & 0.066 & 0.932 \\
\hline Density of the branch roads & -0.043 & 0.051 & 0.958 \\
\hline The number of schools & -0.008 & 0.699 & 0.992 \\
\hline Regional accessibility & $0.174^{*}$ & 0.091 & 1.19 \\
\hline \multicolumn{4}{|l|}{ Transport services } \\
\hline Metro service frequency & 0.092 & 0.11 & 1.096 \\
\hline The number of bus service lines & 0.197 & 0.146 & 1.218 \\
\hline \multicolumn{4}{|l|}{ Household socioeconomic features } \\
\hline Housing price & $0.253^{* * *}$ & 0.094 & 1.288 \\
\hline Monthly income: above RMB 5000 & $0.450^{*}$ & 0.276 & 1.568 \\
\hline Car ownership & 0.067 & 0.29 & 1.069 \\
\hline \multicolumn{4}{|l|}{ Individual personal preferences } \\
\hline Preference for metro transport & 0.386 & 0.272 & 1.445 \\
\hline Preference for driving & -0.61 & 0.454 & 0.543 \\
\hline Dislike travel & 0.0001 & 0.292 & 1.0001 \\
\hline Intercept & 8.558 & 3.344 & 5208.25 \\
\hline Observations & 230 & & \\
\hline $\mathbf{L L}$ & -169.72 & & \\
\hline $\mathrm{Ch}^{\mathrm{i} 2}$ & 27.16 & & \\
\hline sig & 0.004 & & \\
\hline
\end{tabular}

Reference group: not living near the TOD station

\section{$5 \quad$ Discussion and policy implications}

This study examined the effects of land use on individual passengers' choices to reside, shop, and use dining and entertainment facilities in metro station areas in the suburbs of Beijing. Several key arguments relating to the results will be discussed below.

Firstly, the analysis results show that land use does play a role in passengers' choices of consuming in suburban metro station areas when transport services and preferences for travel and housing are taken into account in Beijing. Mixed land use in metro station areas encourages people to do their shopping and use dining and entertainment facilities there. These findings add to those of previous studies (Handy et al., 2005; Handy, 1993; Loutzenheiser, 1997; Fan, Allen, \& Sun, 2014). One reason for this is that a high level of mixed land use usually leads to greater choice in goods and services, which makes metro station areas more attractive. Another reason is that mixed land use in metro station areas brings the convenience of shopping and other linked travel between home, the workplace and the station, such as picking up children and meeting friends (Cervero, 1996). Unfortunately, this study could not provide the evidence of walking friendly on consumption behavior in metro station areas.

Secondly, the effects of land use on passengers' residential location choices tend to be complicated. Results of this study show that land use in Beijing's metro station areas has no significant relationship 
with passengers' choices of residing in those areas when other factors are taken into account. One of these factors is housing prices. Soaring housing prices are still the most important factor affecting residential location choices in Beijing. Many empirical studies in Beijing found the positive effect of metro proximity on housing property value (Zhang et al., 2016; Sun et al., 2015). The accessibility improvements brought up by metro proximity has even led to gentrification in the metro station precincts (Zheng \& Kahn, 2013). This means that in the present stage of urban development, housing ownership or access to low-price rental housing are still very important factors for most passengers. Land use policies which can provide low-price housing could be helpful in encouraging travelers, particularly low-income ones, to live in metro station areas. Since low-income suburban passengers have a stronger tendency to rely on metro systems, these land use policies could also have the co-benefits of improving transport-related social equity in the suburbs.

Thirdly, transport services have substitute effects on land use in relation to their links with passengers' residential location choice and shopping trips in the suburban area in Beijing. This result could also apply to transit planning in other cities and countries. International experiences show that high quality metro services, i.e., frequent, reliable and punctual, could encourage people to live in metro station areas and use the metro more (Arrington \& Cervero, 2008; Pratt, 2013). Similarly, a high quality of bus services around metro stations can encourage people to consume more in metro station areas (Thompson \& Matoff, 2000). In particular, in relation to consumption trips, good bus services result in lower rates of driving and more trips being conducted within a metro station area rather than further afield (Chatman, 2013). However, some researchers disagree with the above conclusions, and have argued that a high level of bus services in metro station areas may encourage people to travel further and, thus, decrease their likelihood to shop and consume near metro station stations (Edwards \& Mackett, 1996; Cervero, 2006). This is called a "substitute effect" of transport services for land use. The results also show that a high level of bus services encourages more shopping trips in Beijing's suburban metro station areas. The results in this study show that a higher level of metro services may not affect an individual passenger's choice to reside in a metro station area when other factors, e.g., housing price and household income, are taken into account. The reason for this might be that the metro service frequency in Beijing is already high, and there are only small differences in frequency between metro station areas (Beijing Transportation Research Center, 2014). A low level of metro service frequency may encourage passengers to do their shopping in the metro station area, although it may discourage people from choosing to travel by metro. Long waiting times offer passengers the opportunity to do their shopping in the metro station area.

Fourthly, there are socioeconomic variations in the effects of land use on passengers' choices of residing and consuming in the metro station area in Beijing This study found that passengers from highincome households are more likely to reside in a metro station area. One of the reasons for this is that in Beijing, metro proximity has a significant premium on housing price nearby. Therefore, residents living near the metro stations in Beijing tend to be more affluent to some extent. Another reason is that many high-income earners still rely on metro services even when they have a car. This is mainly because traffic congestion in the central areas of Beijing is very bad. Inside the area circled by the 3rd Ring Road, the all-day average travel speed by car has decreased from $34 \mathrm{~km} / \mathrm{h}$ in 2009 to $26 \mathrm{~km} / \mathrm{h}$ in 2014. During peak hours, the average speed is $18 \mathrm{~km} / \mathrm{h}$ (Beijing Transportation Research Center, 2014). Additionally, automobile management policies in Beijing such as odd-even license plate travel control also force car owners to consider other travel modes on days when their car travel is restrained.

Many previous studies have shown that personal preferences for transport mode and travel affect people's choices to reside and consume in metro station areas (Lund, 2006; Chatman, 2013; Cao, Mokhtarian, \& Handy, 2009). The present study shows that passengers who dislike travel are more 
likely to consume within metro station areas in Beijing. This provide new evidence for the self-selection theory (Cao et al., 2009). However, their preference for the metro was not one of the important factors leading them to choose to reside in metro station areas. As the above results show, for most passengers who reside in metro station areas in Beijing, other factors such as housing prices and household income may be more important than individual attitudes.

\section{Conclusions}

How do we change the nature of suburban people's mobility and shape it towards a more sustainable way in the process suburbanization? What is the role that land use in metro station areas can play? These questions are important for city or transport planners who work on metro station. This paper investigated the effects of land use on metro users' choices to reside and consume in metro station areas. Using survey data, the study found that mixed land use stimulate more shopping trips. A higher level of regional accessibility and larger area of non-residential land can encourage passengers to make more dining and recreation trips in metro station areas. Land use planning of metro station could be a tool for restraining the increasing long trips made by cars in the suburbs. Lifestyle related mobility, such as shopping, dining and entertainment travel can be affected by metro station planning in the process of suburbanization in China's growing cities. This study provides evidence that China should seize the opportunity of transit-oriented development to integrate transport planning and land use planning in metro station areas to improve business vibrancy and quality of life for residents.

When it comes to residential location choice, land use policy should be assisted by housing policy to encourage passengers to choose to live near metro station areas. The results of our analysis show that land use has no significant relationship with residential location preferences, while housing prices and income have strong ones. The high housing prices nearby transit stations may force people, in particular, low-income people, to live far away from metro station areas. Housing policy should be integrated with land use planning in metro station areas. Land use policies should also be integrated with transport policy. A high level of bus services is important for attracting residents to shopping and dine within metro station areas rather than elsewhere. Those who dislike travelling tend to participate in more shopping and entertainment within metro station areas. Thus, policies designed to create more attractive travel environments for shopping, catering and entertainment within metro station areas may present an opportunity to encourage local trips nearby transit stations.

Several limitations of this study should be acknowledged. Firstly, the analyses focused on metro passengers in metro station areas. Although trips by metro constituted the dominant share of all trips in metro station areas, some people who live in metro station areas do not use the metro but instead travel by bus, walking and/or cycling. A study comparing those who use the metro and those who don't would be valuable for gaining a clearer image of the effects of land use on residential location choice and travel behavior. Secondly, while the study gathered data on the impacts of personal preferences on residential location choice and travel behavior, the analyses and discussion only focused on personal preferences for travel mode. The issue in relation to passengers' preferences for housing, goods and services needs to be addressed in future research. Thirdly, the findings in this study reveal the relationships between land use and passengers' choices for residing and consuming in metro station areas. The causal mechanism for this relationship was not examined by this study. A greater complexity in relationships between land use and passengers' living and travel behaviors could be revealed by future research with longitudinal data.

\section{Acknowledgements}

This research is funded by the NSFC project No. 41571147. The authors thank Nanhui Li very much for her support in data analysis. 


\section{References}

Arrington, G. B., \& Cervero, R. (2008). TCRP report 128: Effects of TOD on housing, parking, and travel. Washington, DC: Transportation Research Board of the National Academies.

Audirac, I. (2003). Information-age landscapes outside the developed world Bangalore, India, and Guadalajara, Mexico. Journal of the American Planning Association, 69, 16-32.

Bartholomew, K., \& Ewing, R. (2011). Hedonic price effects of pedestrian-and transit-oriented development. Journal of Planning Literature, 26, 18-34.

Beijing Municipal Commission of Urban Planning. (2005). Beijing comprehensive planning for 20042020. Retrieved from http://www.bjghw.gov.cn/web/static/catalogs/catalog_233/233.html

Beijing Transportation Research Center. (2013). Beijing transport annual report 2012. Beijing: Beijing Transportation Research Center.

Beijing Transportation Research Center. (2014). Beijing transport annual report 2013. Beijing: Beijing Transportation Research Center.

Bhat, C. R., \& Guo, J. Y. (2007). A comprehensive analysis of built environment characteristics on household residential choice and auto ownership levels. Transportation Research Part B: Methodological, 41, 506-526.

Beijing Municipal Bureau of Statistic. (2015). Beijing statistic yearbook 2015. Beijing, China: Beijing Municipal Bureau of Statistic (BMBS).

Bowes, D. R., \& Ihlanfeldt, K. R. (2001). Identifying the impacts of rail transit stations on residential property values. Journal of Urban Economics, 50, 1-25.

Buire, C. (2014). The dream and the ordinary: An ethnographic investigation of suburbanization in Luanda. African Studies, 73, 290-312.

Cao, X. J., Mokhtarian, P. L., \& Handy, S. L. (2009). The relationship between the built environment and nonwork travel: A case study of Northern California. Transportation Research Part A: Policy and Practice, 43, 548-559.

Cervero, R. (1996). Mixed land-uses and commuting: Evidence from the American Housing Survey. Transportation Research Part A: Policy and Practice, 30, 361-377.

Cervero, R. (2004). Transit-oriented development in the United States: Experiences, challenges, and prospects. Washington, DC: Transportation Research Board.

Cervero, R. (2006). Office development, rail transit, and commuting choices. Journal of Public Transportation, 9, 41-55.

Cervero, R., \& Day, J. (2008). Suburbanization and transit-oriented development in China. Transport Policy, 15, 315-323.

Cervero, R., \& Duncan, M. (2002). Transit's value-added effects: Light and commuter rail services and commercial land values. Transportation Research Record, 1805, 8-15.

Cervero, R., \& Murkami, J. (2009). Rail and property development in Hong Kong: Experiences and extensions. Urban Studies, 46, 2019-2043.

Cervero, R., Sarmiento, O. L., Jacoby, E., Gomez, L. F., \& Neiman, A. (2009). Influences of built environments on walking and cycling: Lessons from Bogotá. International Journal of Sustainable Transportation, 3, 203-226.

Chatman, D. G. (2013). Does TOD need the T? On the importance of factors other than rail access. Journal of the American Planning Association, 79, 17-31.

Curtis, C. (2008). Evolution of the transit-oriented development model for low-density cities: A case study of Perth's new railway corridor. Planning, Practice and Research, 23, 285-302.

David, S. (2010). Confidence intervals for negative binomial random variables of high dispersion. The International Journal of Biostatistics, 6, 1-41. 
Dittmar, H., \& Ohland, G. (2012). The new transit town: Best practices in transit-oriented development. Washington DC: Island Press.

Doulet, J.-F., Delpirou, A., \& Delaunay, T. (2017). Taking advantage of a historic opportunity? A critical review of the literature on TOD in China. Journal of Transport and Land Use, 10, 77-92.

Du, C., \& Jiang, Y. (2005). Connection of urban rail transit with other public transportations. Urban Rapid Rail Transit, 18, 45-49.

Edwards, M., \& Mackett, R. L. (1996). Developing new urban public transport systems: An irrational decision-making process. Transport Policy, 3, 225-239.

Ewing, R. H. (2008). Characteristics, causes, and effects of sprawl: A literature review. Urban ecology. Berlin: Springer.

Fan, Y., Allen, R., \& Sun, T. (2014). Spatial mismatch in Beijing, China: Implications of job accessibility for Chinese low-wage workers. Habitat International, 44, 202-210.

Frank, L. D., \& Pivo, G. (1994). Impacts of mixed use and density on utilization of three modes of travel: Single-occupant vehicle, transit, and walking. Transportation Research Record, 1466, 44-52.

Glenn, N. D. (1973). The urbanization of the suburbs. In Suburbanization in the United States since World War II. Beverly Hills, CA: Sage.

Gordon, P., Kumar, A., \& Richardson, H. W. (1989). The influence of metropolitan spatial structure on commuting time. Journal of Urban Economics, 26, 138-151.

Gu, Y., \& Zheng, S. (2010). The impacts of rail transit on property values and land development intensity: The case of No. 13 Line in Beijing. Acta Geographica Sinica, 65, 213-223.

Handy, S. (1993). Regional versus local accessibility: Implications for nonwork travel. Berkeley, CA: University of California Transportation Center.

Handy, S., Cao, X., \& Mokhtarian, P. (2005). Correlation or causality between the built environment and travel behavior? Evidence from Northern California. Transportation Research Part D: Transport and Environment, 10, 427-444.

Handy, S., Cao, X., \& Mokhtarian, P. L. (2006). Self-selection in the relationship between the built environment and walking: Empirical evidence from Northern California. Journal of the American Planning Association, 72, 55-74.

Handy, S. L. (1996). Understanding the link between urban form and nonwork travel behavior. Journal of Planning Education and Research, 15, 183-198.

Hess, D. B., \& Almeida, T. M. (2007). Impact of proximity to light rail rapid transit on station-area property values in Buffalo, New York. Urban Studies, 44, 1041-1068.

Hilbe, J. M. (2011). Negative binomial regression. Cambridge, UK: Cambridge University Press.

Huang, H., Yin, Q., Schwebel, D. C., Li, L., \& Hu, G. (2016a). Examining road traffic mortality status in China: A simulation study. PLoS One, 11, e0153251.

Huang, S., Guan, H., \& Yan, H. (2009). A study on urban railway connection mode selections in Beijing. China Civil Engineering Journal, 42, 126-130.

Huang, X., Cao, X., \& Cao, J. (2016b). The association between transit access and auto ownership: Evidence from Guangzhou, China. Transportation Planning and Technology, 39, 269-283.

Huang, X., Cao, X., \& Cao, X. (2016c). The association between transit access and auto ownership: Evidence from Guangzhou, China. Transportation Planning and Technology, 39, 269-283.

Huang, X., Cao, X., Yin, J., \& Cao, X. (In press). Effects of metro transit on the ownership of mobility instruments in Xi'an, China. Transportation Research Part D: Transport and Environment.

Jordon, S., Ross, J. P., \& Usowski, K. G. (1998). US suburbanization in the 1980s. Regional Science and Urban Economics, 28, 611-627.

Kahimbaara, J. A. (1986). The population density gradient and the spatial structure of a third world city: Nairobi, a case study. Urban Studies, 23, 307-322. 
Loutzenheiser, D. (1997). Pedestrian access to transit: Model of walk trips and their design and urban form determinants around Bay area rapid transit stations. Transportation Research Record, 1640, $40-49$.

Lund, H. (2006). Reasons for living in a transit-oriented development, and associated transit use. Journal of the American Planning Association, 72, 357-366.

Lund, H. M., Cervero, R., \& Wilson, R. W. (2004). Travel characteristics of transit-oriented development in California. Berkeley, CA: University of California Transportation Center.

Mieszkowski, P., \& Mills, E. S. (1993). The causes of metropolitan suburbanization. The Journal of Economic Perspectives, 7, 135-147.

Mu, R., \& Jong, M. D. (2012). Establishing the conditions for effective transit-oriented development in China: The case of Dalian. Journal of Transport Geography, 24, 234-249.

National Development and Reform Commission. (2014). National new urbanization Plan (20142020). In Commission, N. D. A. R. (ed.). Beijing.

Niles, J., \& Nelson, D. A. (1999). Prerequisite to planning for transit-oriented development: Understanding non-work activity location patterns and trends. Paper presented at the Seventh National Conference on the Application of Transportation Planning Methods, Transportation Research Board, Washington, DC

Olaru, D., Smith, B., \& Taplin, J. H. E. (2011). Residential location and transit-oriented development in a new rail corridor. Transportation Research Part A: Policy and Practice, 45, 219-237.

Ping Wang, Y., \& Murie, A. (1996). The process of commercialization of urban housing in China. Urban Studies, 33, 971-989.

Prashker, J., Shiftan, Y., \& Hershkovitch-Sarusi, P. (2008). Residential choice location, gender and the commute trip to work in Tel Aviv. Journal of Transport Geography, 16, 332-341.

Pratt, R. H. (2013). Chapter 1-Introduction, In Traveler response to transportation system changes handbook. Washington DC: Transportation Research Board.

Pucher, J., Peng, Z., Mittal, N., Zhu, Y. and Korattyswaroopam, N. (2007). Urban transport trends and policies in China and India: Impacts of rapid economic growth. Transport Reviews, 27(4), 379-410.

Ratner, K. A., \& Goetz, A. R. (2013). The reshaping of land use and urban form in Denver through transit-oriented development. Cities, 30, 31-46.

Shen, Q., Chen, P., \& Pan, H. (2016). Factors affecting car ownership and mode choice in rail transitsupported suburbs of a large Chinese city. Transportation Research Part A: Policy and Practice, 94, $31-44$.

Sun, W., Zheng, S., \& Wang, R. (2015). The capitalization of subway access in home value: A repeatrentals model with supply constraints in Beijing. Transportation Research Part A: Policy and Practice, $80,104-115$.

Switzer, C. (2002). The center commons transit oriented development: A case study. Portland, OR: Master of Urban and Regional Planning, Portland State University.

The State Council. (2012). Opinions on encouraging development of public transit in China. In: COUNCIL, T. S. (ed.). Beijing.

Thompson, G. L., \& Matoff, T. G. (2000). Network philosophy affects performance of transit investments in US urban areas. Paper presented at the 8th Joint Conference on Light Rail Transit.

United Nations. (2001). Cities in a globalizing world: Global report on human settlements. New York: United Nations.

Walcott, S. M. (2002). Chinese industrial and science parks: Bridging the gap. The Professional Geographer, 54, 349-364.

Wang, D., \& Zhou, M. (In press). The built environment and travel behavior in urban China: A literature review. Transportation Research Part D: Transport and Environment. 
Wang, F., \& Wang, D. (2014). Characteristics and determinants of car use in Beijing. Acta Geographica Sinica, 69, 771-781.

Wang, Y. P., \& Murie, A. (2000). Social and spatial implications of housing reform in China. International Journal of Urban and Regional Research, 24, 397-417.

Wei, Y. H., Lu, Y., \& Chen, W. (2009). Globalizing regional development in Sunan, China: Does Suzhou Industrial Park fit a neo-Marshallian district model? Regional Studies, 43, 409-427.

Wu, X., Wu, Y., Zhang, S., Liu, H., Fu, L., \& Hao, J. (2016). Assessment of vehicle emission programs in China during 1998-2013: Achievement, challenges and implications. Environmental Pollution, 214, 556-567.

Zhang, M. (2007). Chinese edition of transit-oriented development. Transportation Research Record, 2038, 120-128.

Zhang, Y., Zheng, S., Sun, C., \& Wang, R. (2016). Does subway proximity discourage automobility? Evidence from Beijing. Transportation Research Part D: Transport and Environment, 52, 506-517.

Zhao, P. (2010). Sustainable urban expansion and transportation in a growing megacity: Consequences of urban sprawl for mobility on the urban fringe of Beijing. Habitat International, 34, 236-243.

Zhao, P. (2011). Managing urban growth in a transforming China: Evidence from Beijing. Land Use Policy, 28, 96-109.

Zhao, P. (2013a). The impact of urban sprawl on social segregation in Beijing and a limited role for spatial planning. Tijdschrift voor Economische en Sociale Geografie, 104, 571-587.

Zhao, P. (2013b). Too complex to be managed? New trends in peri-urbanization and its planning in Beijing. Cities, 30, 68-76.

Zhao, P., Bin, L., \& de Roo, G. (2010). Urban expansion and transportation: The impact of urban form on commuting patterns on the city fringe of Beijing. Environment and Planning A, 42, 2467-2486.

Zheng, S., \& Kahn, M. E. (2013). Does government investment in local public goods spur gentrification? Evidence from Beijing. Real Estate Economics, 41, 1-28.

Zhongshang Industrial Research. (2016). Public transit industrial research in China 2016. Retrieved from http://mt.sohu.com/20160506/n447960456.shtml 